\title{
COMUNICACÕES
}

\section{Occurrence of leaf blast on white oats, Italian ryegrass and wheat in Southern Brazil}

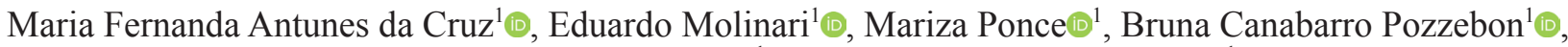 \\ Renata Silva Canuto de Pinho ${ }^{1}\left[{ }^{0}\right.$, Eduardo Bohrer de Azevedo ${ }^{1}[0$
}

${ }^{1}$ Universidade Federal do Pampa, Campus Itaqui, Rua Luiz Joaquim de Sá Brito, sn, Bairro Promorar, Itaqui, RS, Brasil, CEP:97650-000 Corresponding Author: Maria Fernanda Antunes da Cruz (mariacruz@unipampa.edu.br)

Data de chegada: 24/03/2020. Aceito para publicação em: 19/11/2020.

$10.1590 / 0100-5405 / 235504$

Fungi of the genus Pyricularia are widely known to cause rice blast and have also infected other commercially important grasses such as forage, wheat and oats. In Brazil, wheat blast was initially identified in northern Paraná in 1985 (1), affecting black oats in 2006 (4), white oats in 2012 (3) and Italian ryegrass in 2001 in Rio Grande do Sul State (5).

At the experimental area of Federal University of Pampa, Itaqui Campus, Rio Grande do Sul State, Brazil, located at 2909'19.9'S and $56^{\circ} 33>16.9$ » W, on 08/08/2019, plants of Lolium multiflorum
Lam. (weed and cultivar 'Barjumbo'), Avena sativa L. (cultivar 'IP Esmeralda'), and Triticum aestivum L. (cultivar 'BRS Tarumã') were found to have characteristic leaf blast symptoms, which included elliptical to elongate lesions showing white to light brown centers and dark grey to reddish-brown borders $(1,2)$. Plants with symptoms of blast were collected and prepared for the humid chamber. Leaf regions with these symptoms were sectioned and disinfected in $1 \%$ sodium hypochlorite for three minutes, followed by washing with water. Then,
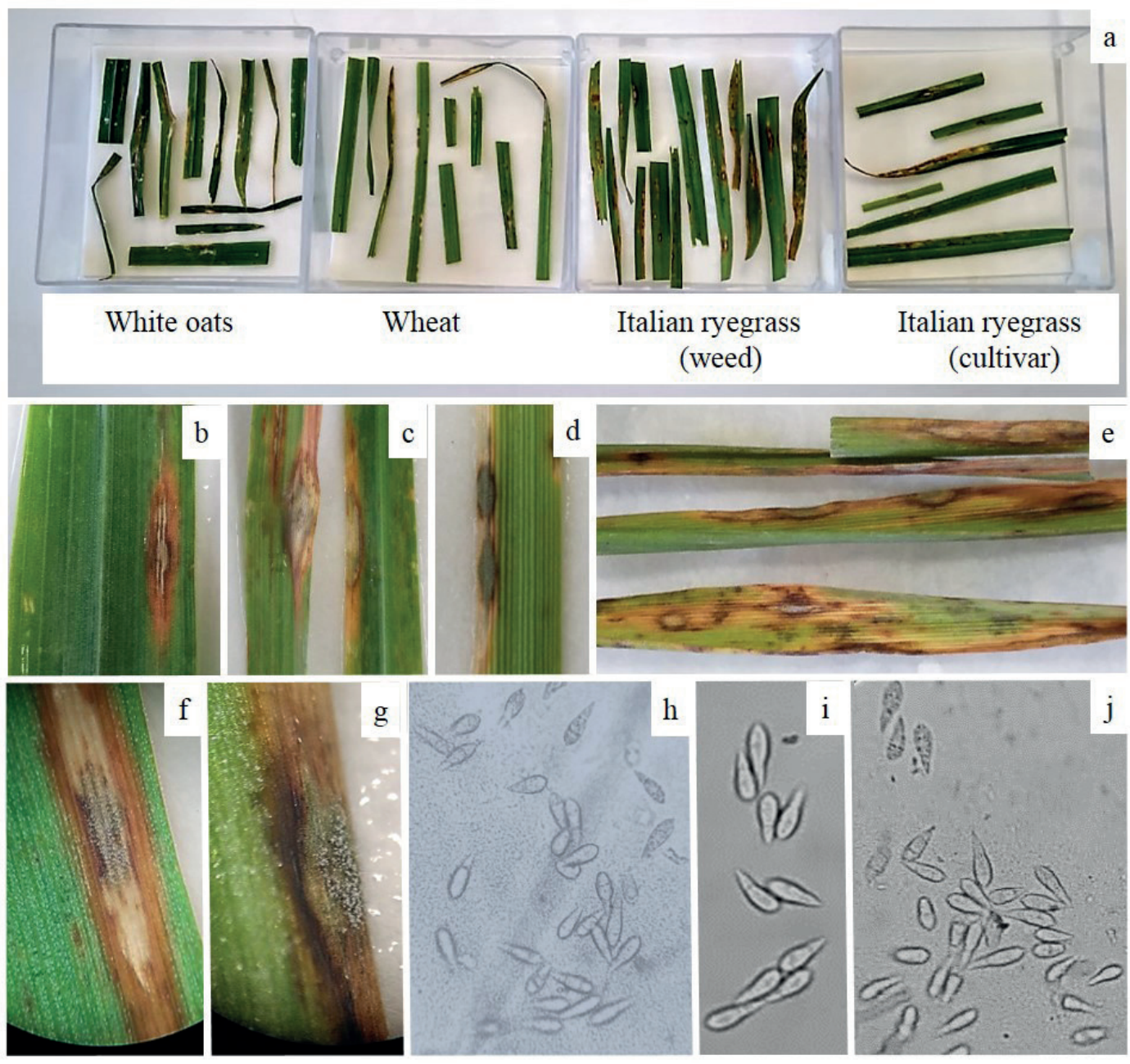

Figure 1. Identification of the fungus Pyricularia on leaf samples from white oats, Italian ryegrass and wheat. a- Samples in humid chamber, b and c- White oat blast lesion (Cultivar 'IP Esmeralda'), d- Wheat blast sporulative lesions (Cultivar 'Tarumã'), e- Italian ryegrass blast lesion (Cultivar 'Barjumbo' and weed), f and g- Images obtained under a stereoscopic microscope: conidiophores and conidia of Pyricularia on white oat (f) and Italian ryegrass (g) samples, approximately 24 hours in a growth chamber. h-j- Images of Pyricularia conidia by light microscopy. h- White oats, i-Wheat, j- Italian ryegrass. 
the samples were placed in a "gerbox" containing filter paper and kept at $25^{\circ} \mathrm{C}$ and $12 \mathrm{~h}$ light/dark photoperiod, in a growth chamber, for 24 hours (Figure 1a). Under a stereoscopic microscope, Italian ryegrass, oats and wheat samples showed the presence of densely sporulative Pyricularia sp. lesions (Figure 1b-g). Hyaline pyriform conidia with three cells typical of Pyricularia sp. were observed on the lesions (Figura 1h-j). From the samples, monosporic isolations of the fungus were performed. The fungal colony was peeled into Petri dishes containing oat-agar and maintained for twelve days in a growth chamber $\left(25^{\circ} \mathrm{C}\right.$ and $12 \mathrm{~h}$ light photoperiod) until inoculation. Plants of wheat (cultivar 'Tarumã'), Italian ryegrass (cultivar 'Barjumbo'), and white oats (cultivar 'IP Esmeralda') showing four fully expanded leaves were inoculated with a conidial suspension of Pyricularia $s p$. at $1.0 \times 10^{5}$ conidia/ $\mathrm{mL}$, obtained from the respective hosts, for the application of Koch's Postulates. After inoculation, the plants were subjected to an initial $24 \mathrm{~h}$ dark period, followed by $12 \mathrm{~h}$ light, at $25 \pm 2{ }^{\circ} \mathrm{C}$ and $90 \pm 5 \%$ relative humidity. The first symptoms of the disease occurred 48 hours after inoculation. The typical blast lesions were elliptical and had brownish edges and sporulative gray center. Re-isolation of the pathogen from the lesions produced on the inoculated leaves confirmed the occurrence of Pyricularia sp. causing blast in the samples.

This is the first report of Pyricularia sp. infection in Italian ryegrass, white oats and wheat in the same area, at the western frontier of Rio Grande do Sul State. This is characterized as the main rice producer region in the country; however, wheat and oat crops are not common in this region, since during the fall the soil remains fallow or covered with pasture. Identification of blast symptoms in these species reinforces the recent attention given to the correct name of the different species of this pathogen, its damage to various countries and grass crops, and the importance of the initial inoculum at the beginning of an epidemic (2).

\section{REFERENCES}

1. Igarashi, S.; Utiamada, C.M.; Igarashi, L.C.: Kazuma, A.H.: Lopes, R.S. Pyricularia sp. Em trigo. I. Ocorrência de Pyricularia sp. No estado do Paraná. In: Reunião Nacional de Pesquisa de Trigo, 14., 1986, Londrina. Resumos. Londrina: IAPAR, 1986. p.57.

2. Ceresini, P.C.; Castroagudín, V.L.; Rodrigues, F.A.; Rios, J.A.; Aucique-Pérez, C.A.; Moreira, S.I.; Croll, D.; Alves, E.; Carvalho, G.; Maciel, J.L.N.; Mcdonald, B.A. Wheat blast: from its origins in South America to its emergence as a global threat. Molecular Plant Pathology, London, v.20, n.2, p.155-172, 2019.

3. Marangoni, M.S.; Nunes, M.P.; Fonseca Júnior, N.; Mehta, Y.R. Pyricularia blast on white oats - a new threat to wheat cultivation. Tropical Plant Pathology, Viçosa, v.38, n.3, p.198-202, 2013.

4. Mehta, Y.R.; Nunes, M.P.; Oliveira, J.C. Ocorrência de brusone em aveia no Estado do Paraná. In: Reunião da Comissão Brasileira de Pesquisa de Aveia, 26., 2006, Guarapuava. Resumos. Guarapuava: FAPA, 2006. p.55-57.

5. Nunes, C.D.M.; Brancão, N.; Rodriques R.C.; Reis, J.C. Ocorrência de brusone em azevém. Fitopatologia Brasileira, Brasília, DF, v.27, supl., p.803, 2002. (Resumo). 